\title{
EGE BÖLGESİ EGE BÖLÜMÜ HALKEVLERİ VE YAYIN ÇALIŞMALARI*
}

Yard. Doç. Dr. Mustafa ÖZSARI**

Ben konuşmamda Ege bölgesinde 1932-1950 yılları arasında açılan halkevlerinden ve halkevleri çalışmalarının önemli bir cephesini oluşturan yayın çalışmalarından söz etmek istiyorum. Ege'de açllan halkevlerinin Türkiye genelinde faaliyette bulunan bütün halkevlerinin yaklaşık \%16'sını oluşturduğu dikkate alınırsa, kısa bir süreyle sınırlanmış konuşmada söz konusu kurumların değişik boyutlarıyla değerlendirilmesi zaten mümkün değildir. Kaldı ki İzmir, Aydın, Denizli, Manisa gibi Ege'nin büyük kültür merkezlerindeki halkevlerinin faaliyetlerinde, kişiye bağlı olmaktan kurtulup belirli bir kurumlaşmaya doğru gittiği bilinmektedir. Bu yüzden Ege bölgesinde açılan halkevlerine dair doğru bir analiz yapmak için, başta adı geçen halkevleri olmak üzere, bölgede açılan diğer halkevleri faaliyetlerinin ayrı ayrı incelenmesi gerekir. Böylece Cumhuriyet dönemi kültür hayatında önemli bir yere sahip olan halkevlerinin mahiyetlerinin tam olarak ne olduğu -en azından Ege bölgesi açısından- kısmen ortaya çıkmış olacaktır.

\section{EGE BÖLÜMÜ HALKEVLERİ}

Adını kıyısı olduğu Ege Denizi'nden alan Ege bölgesi, İzmir, Manisa, Denizli, Aydın, Muğla, Uşak, Kütahya ve Afyon illerini kapsar. Ege bölgesi coğrafî açıdan Ege bölümü ve iç batı Anadolu bölümü olmak üzere iki aslî bölüme ayrılır'. "Ege bölümü, bölgenin battya, Ege denizine ge-

* 6 Mart 2002 Çarşamba günü Ege Üniversitesi Edebiyat Fakültesinde düzenlenen "Halkevlerinin Kuruluşunun 70. Yıldönümü Anma Programı"nda sunulan bildirinin metnidir.

** Balıkesir Üniversitesi Fen-Edebiyat Fakültesi Türk Dili ve Edebiyatı Bölümü Öğretim Üyesi.

1. Birinci Coğrafya Kongresi (6-21 Haziran 1941), Raporlar, Müzakereler, Kararlar, bty., s.78. 
niş bir cephe ile açılan kısmını meydana getirir" ${ }^{\text {2 }}$. İzmir, Aydın, Muğla, Manisa ve Denizli Ege bölümünde; Uşak, Kütahya ve Afyon ise İç batı Anadolu bölümünde yer alır. Ege bölgesinin önemli kültür merkezleri de olan bu illerde çok sayıda halkevi açılmıştır. Burada konunun genişliği göz önüne alınarak, Ege bölgesinin tamamında faaliyette bulunan halkevleri değil, sadece Ege bölümündeki halkevleri ele alınacak ve bu halkevlerinin yayın cephesi değerlendirmeye tabi tutulacaktır. Ege bölümünden söz edilirken yaygın kullanılış dikkate alınarak "Ege Bölgesi Halkevleri" ifadesi tercih edilecektir. Başka deyişle "Ege Bölgesi Halkevleri" ifadesinden İzmir, Aydın, Denizli, Manisa ve Muğla illeri ve bu iller dahilinde açılan halkevleri anlaşılmalıdır. Halkevleri faaliyetlerine dair C.H.P. tarafından 1950'de yayımlanan son halkevi broşürüne göre ${ }^{3}$ İzmir'de 22, Denizli'de 20, Aydın ve Manisa'da 15'er ve Muğla'da 7 halkevi açılmıştır. Bu rakam Türkiye genelinde açılan 478 halkevinden 79'unun, bir başka ifadeyle \% 16'sının Ege bölgesinde kurulduğunu göstermektedir. Yani Ege bölgesindeki halkevleri sayıca diğer bölgelerdekinden fazladır. İnceleme konumuzun halkevleri yayın çalışmaları olması dolayısıyla, burada söz konusu vilâyetlerde açılan halkevlerine kısaca değinilecek ve halkevleri yayınlarına dair mevcut kaynaklara dayanarak bilgi vermek yoluna gidilecektir.

1.1. İzmir Halkevleri: İzmir il sınırları içinde toplam 22 halkevi açılmış ve faaliyette bulunmuştur ${ }^{4}$. İzmir'de açılan ilk halkevi İzmir Halkevi'dir. İzmir Halkevi 19 Şubat 1932 Cuma günü resmen açılmış ve faaliyetlerine başlamıştır. 19 Şubat 1932-24 Şubat 1946 tarihleri arasında İzmir ve ilçelerinde açılan halkevlerinin adları şöyledir: Urla, Bergama, Ödemiş, Tire, Bayındır, Çeşme, Dikili, Karşıyaka, Kemalpaşa, Kınık, Kiraz, Menemen, Adagide, Bademiye, Birgi, Kaymakçı, Bornova, Buca, Torbalı, Kuşadası. Ayrıca açılış tarihine dair elimizde herhangi bir kayıt olmamakla birlikte, Seferihisar'da da bir halkevi açıldığını biliyoruz. Bu halkevlerinden bazılarının kültürel anlamda önemli sayılabilecek bir çalışması yoktur. Bununla beraber gerek yayımladıkları dergiler, gerekse kültürel alandaki diğer çalışmalarıyla İzmir, Bergama, Karşıyaka, Ödemiş, Urla ve Tire'deki halkevleri adlarından söz ettiren birer kültür kuru-

2. Asaf Koçman, Insan Faaliyetleri ve Çevre Üzerine Etkileri Açısından Ege Ovalarının İklimi, Ege Üniversitesi Edebiyat Fakültesi Yayınları, nr. 73, s. 1.

3. C.H.P. 18. Ylldönümünde Halkevleri ve Halkodalar, Ulus Basımevi, Ankara: 1950, s. 7.

4. C.H.P. 18. Yıldönümünde Halkevleri ve Halkodaları, s. 7. 
mu olmayı başarmışlardır. Örneğin İzmir Halkevi daha açıldığı ilk günlerden itibaren, talimatnamede belirtilen hemen her alanda çalışma yaparken, Karşıyaka Halkevi lâik Türkiye'nin benimsediği yeni hayat anlayışı doğrultusunda düzenlenen eğlenceli balolar, garden partiler, kültür geceleri ve konserlerle dikkati çeker. Gerek İzmir gerekse Karşıyaka halkevlerindeki bu faaliyetler Anadolu, Halkın Sesi ve Yeni Asır gibi İzmir'de ç1kan günlük gazeteler aracılığıyla halka birkaç gün önceden duyurulmuş, böylece halkevi faaliyetlerine geniş bir katılım sağlanmıştır.

Tablo 1: İzmir Halkevleri ve Açılış Tarihleri

\begin{tabular}{|c|c|}
\hline \multicolumn{2}{|c|}{ İMIR HALKEVLERİ } \\
\hline Halkevinin Adı & Açılış Tarihi \\
\hline İzmir Halkevi & 19 Şubat 1932 \\
\hline Urla Halkevi & 24 Şubat 1933 \\
\hline Bergama Halkevi & 22 Şubat 1934 \\
\hline Ödemiş Halkevi & 22 Şubat 1934 \\
\hline Tire Halkevi & 22 Şubat 1935 \\
\hline Bayındır Halkevi & 20 Şubat 1938 \\
\hline Çeşme Halkevi & 20 Şubat 1938 \\
\hline Dikili Halkevi & 20 Şubat 1938 \\
\hline Karşıyaka Halkevi & 20 Şubat 1938 \\
\hline Kemalpaşa Halkevi & 20 Şubat 1938 \\
\hline Kınık Halkevi & 20 Şubat 1938 \\
\hline Kiraz Halkevi & 20 Şubat 1938 \\
\hline Menemen Halkevi & 20 Şubat 1938 \\
\hline Adagide Halkevi & 19 Şubat 1939 \\
\hline Bademiye Halkevi & 19 Şubat 1939 \\
\hline Birgi Halkevi & 19 Şubat 1939 \\
\hline Kaymakçı Halkevi & 19 Şubat 1939 \\
\hline Bornova Halkevi & 21 Şubat 1943 \\
\hline Buca Halkevi & 21 Şubat 1943 \\
\hline Torbalı Halkevi & 21 Şubat 1943 \\
\hline Kuşadası Halkevi & 24 Şubat 1946 \\
\hline Seferihisar Halkevi & $?$ \\
\hline
\end{tabular}


1.2. Aydın Halkevleri: Türkiye'de ilk defa 14 merkezde açılan halkevlerinden biri de Aydın Halkevi'dir. Aydın vilâyet sınırları içinde 20 Şubat 1945 tarihine kadar toplam 15 halkevi açılmış ve faaliyette bulunmuştur: Bunlar Aydın, Nazilli, Söke, Çine, Bozdoğan, Germencik, Horsunlu, Karacasu, Kılavuzlar, Sultanhisar, Umurlu, Yenipazar ve Kuyucak halkevleridir. Ayrıca İncirliova ve Sümer'de de birer halkevi açıldığ $\breve{b}_{1}$ bilinmekle beraber bu halkevlerinin açılış tarihlerini tespit edemedik. Bilhassa Aydın, Nazilli ve Söke halkevleri yayın konferans, temsil v.b. çalışmalarıyla dikkati çeker. Aydın'da çıkan Ant gazetesi ve Kültür dergisi aracılığıyla Aydın Halkevi çalıșmaları halka duyurulmuş ve adı geçen yayın organlarında halkevi sayfaları açılmıştır.

Tablo 2: Aydın Halkevleri ve Açılış Tarihleri

\begin{tabular}{|l|l|}
\hline \multicolumn{2}{|c|}{ AYDIN HALKEVLERI } \\
\hline Halkevinin Adı & Açlış Tarihi \\
\hline Aydın Halkevi & 19 Şubat 1932 \\
\hline Nazilli Halkevi & 23 Şubat 1933 \\
\hline Söke Halkevi & 22 Şubat 1935 \\
\hline Çine Halkevi & 20 Şubat 1938 \\
\hline Bozdoğan Halkevi & 19 Şubat 1939 \\
\hline Germencik Halkevi & 19 Şubat 1939 \\
\hline Horsunlu Halkevi & 19 Şubat 1939 \\
\hline Karacasu Halkevi & 19 Şubat 1939 \\
\hline Kılavuzlar Halkevi & 19 Şubat 1939 \\
\hline Sultanhisar Halkevi & 19 Şubat 1939 \\
\hline Umurlu Halkevi & 19 Şubat 1939 \\
\hline Yenipazar Halkevi & 19 Şubat 1939 \\
\hline Kuyucak Halkevi & 25 Şubat 1945 \\
\hline İncirliova Halkevi & $?$ \\
\hline Sümer Halkevi & $?$ \\
\hline
\end{tabular}

1.3. Denizli Halkevleri: Denizli'de toplam 20 halkevi açılmıştır. Denizli il merkezi, ilçe ve bucaklarda açılan halkevlerinin adları şöyledir: Denizli, Acıpayam, Sarayköy, Tavas, Buldan, Akalan, Babadağ, Bekili, Çal, Çivril, Güney, Hançalar, Honaz, Kale, Kızılca, Kızılhisar, Nikler, 
Süller, Yeşilyuva ve Zeyve. Denizli'deki halkevlerinin çoğunun 19 Şubat 1939'da açılması dikkat çekici bir durumdur. Bu halkevlerinden Denizli merkezde açılan halkevi dışındaki halkevlerinin ne tür çalışmalar yaptığına dair bilgi bulamadık. Fakat ilk açılan halkevlerinden biri olan Denizli halkevi nitelikli temsiller vermesi, sportif etkinliklerde bulunması ve İnanç dergisini yayımlaması bakımından kayda değer bir kurumdur.

Tablo 3: Denizli Halkevleri ve Açıllş Tarihleri

\begin{tabular}{|c|c|}
\hline \multicolumn{2}{|c|}{ DENIZLİ HALKEVLERİ } \\
\hline Halkevinin Adı & Açılış Tarihi \\
\hline Denizli Halkevi & 19 Şubat 1932 \\
\hline Acıpayam Halkevi & 23 Şubat 1936 \\
\hline Sarayköy Halkevi & 21 Şubat 1937 \\
\hline Tavas Halkevi & 21 Şubat 1937 \\
\hline Buldan Halkevi & 20 Şubat 1938 \\
\hline Akalan Halkevi & 19 Şubat 1939 \\
\hline Babadağ Halkevi & 19 Şubat 1939 \\
\hline Bekili Halkevi & 19 Şubat 1939 \\
\hline Çal Halkevi & 19 Şubat 1939 \\
\hline Çivril Halkevi & 19 Şubat 1939 \\
\hline Güney Halkevi & 19 Şubat 1939 \\
\hline Hançalar Halkevi & 19 Şubat 1939 \\
\hline Honaz Halkevi & 19 Şubat 1939 \\
\hline Kale Halkevi & 19 Şubat 1939 \\
\hline Kızılca Halkevi & 19 Şubat 1939 \\
\hline Kızılhisar Halkevi & 19 Şubat 1939 \\
\hline Nikler Halkevi & 19 Şubat 1939 \\
\hline Süller Halkevi & 19 Şubat 1939 \\
\hline Yeşilyuva Halkevi & 19 Şubat 1939 \\
\hline Zeyve Halkevi & 19 Şubat 1939 \\
\hline
\end{tabular}

1.4. Manisa Halkevleri: Manisa il merkezinde açılan Manisa Halkevi başta olmak üzere, Manisa'da 15 halkevi kurulmuştur. Bu halkevlerinin açıldıkları merkezleri şöyle sıralayabiliriz: Manisa, Kula, Alaşehir, 
Salihli, Akhisar, Turgutlu, Kırkağaç, Demirci, Gölmarmara, Gördes, Muradiye, Sarıgöl, Soma ve Yayaköy. Manisa'da açılan halkevlerinin de önemli bir kısmı, tıpkı Denizli'de olduğu gibi 19 Şubat 1939'da açılır. Ayrıca 24 Şubat 1946 tarihinde Ahmetli halkodası halkevine çevrilmiştir ${ }^{5}$.

Tablo 4: Manisa Halkevleri ve Açılış Tarihleri

\begin{tabular}{|l|l|}
\hline \multicolumn{2}{|c|}{ MANISA HALKEVLERI } \\
\hline Halkevinin Adı & A̧̧ılıs Tarihi \\
\hline Manisa Halkevi & 24 Şubat 1933 \\
\hline Kula Halkevi & 22 Şubat 1934 \\
\hline Alaşehir Halkevi & 22 Şubat 1935 \\
\hline Akhisar Halkevi & 23 Şubat 1936 \\
\hline Salihli Halkevi & 23 Şubat 1936 \\
\hline Turgutlu Halkevi & 23 Şubat 1936 \\
\hline Kurkağaç Halkevi & 21 Şubat 1937 \\
\hline Demirci Halkevi & 20 Şubat 1938 \\
\hline Gölmarmara Halkevi & 19 Şubat 1939 \\
\hline Gördes Halkevi & 19 Şubat 1939 \\
\hline Muradiye Halkevi & 19 Şubat 1939 \\
\hline Sarı̈öl Halkevi & 19 Şubat 1939 \\
\hline Soma Halkevi & 19 Şubat 1939 \\
\hline Yayaköy Halkevi & 19 Şubat 1939 \\
\hline Ahmetli Halkevi & 24 Şubat 1946 \\
\hline
\end{tabular}

1.5. Muğla halkevleri: Muğla ili sınırları içinde 7 halkevi açılır. $\mathrm{Bu}$ kurumların adları ve açıldıklanı yerler şöyledir: Muğla, Milâs, Fethiye, Marmaris, Köyceğiz, Yatağan ve Bodrum. Muğla ve Milâs halkevleri k1sıtlı imkânlarla birer dergi yayımlamışlardır.

5. Hakkı Uyar, Cunhuriyet Döneminde Manisa'da Eğitim (1923-1950), (Basılmamış Yüksek Lisans Tezi), Dokuzeylül Üniversitesi, A.İ.İT.E., İzmir: 1993, s. 66. Ayrıca Ahmetli Halkevi için bkz. C.H.P. 1945 Yılında Halkevleri ve Halkodaları, Ankara: 1946. s. 28 . 
Tablo 5: Muğla Halkevleri ve Açılış Tarihleri

\begin{tabular}{|l|l|}
\hline \multicolumn{2}{|c|}{ MUĞLA HALKEVLERİ } \\
\hline Halkevinin Adı & Açılı̧ Tarihi \\
\hline Muğla Halkevi & 24 Şubat 1933 \\
\hline Milâs Halkevi & 23 Şubat 1934 \\
\hline Fethiye Halkevi & 23 Şubat 1936 \\
\hline Marmaris Halkevi & 19 Şubat 1939 \\
\hline Köyceğiz Halkevi & 21 Şubat 1943 \\
\hline Yatağan Halkevi & 24 Şubat 1946 \\
\hline Bodrum Halkevi & $?$ \\
\hline
\end{tabular}

Grafik 1: Ege Bölgesi Halkevlerinin Açılış Tarihleri Dağılımı Grafiği.

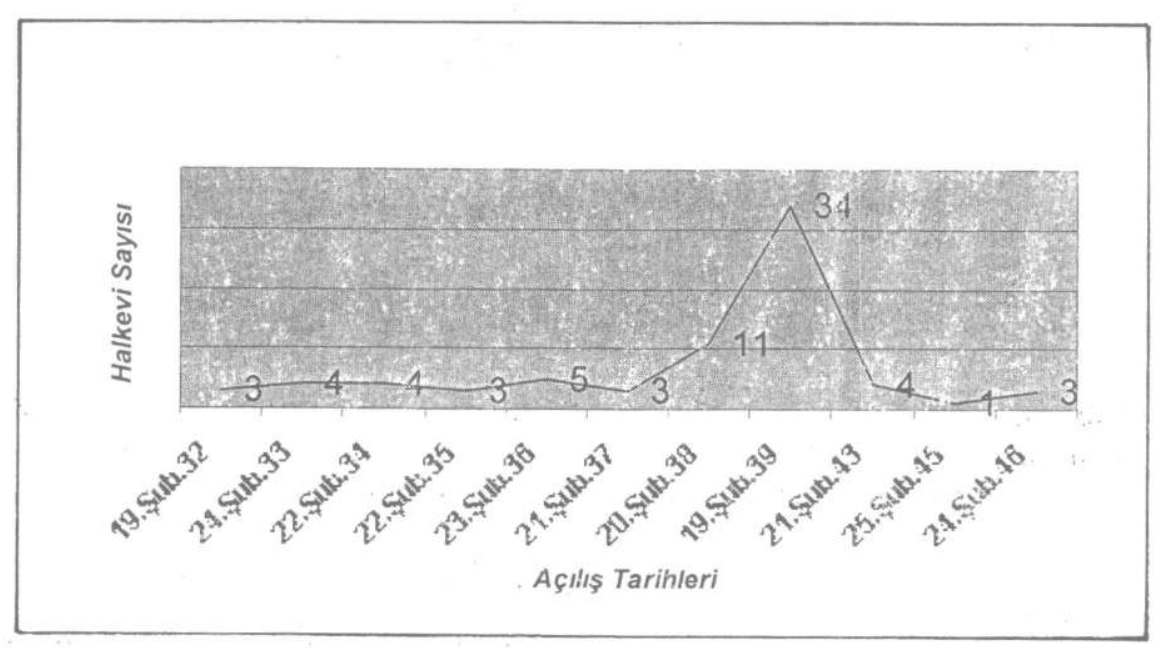

Grafikte görüldüğü gibi 19 Şubat 1932'de, yani halkevlerinin ilk açıldığı zaman Ege bölgesinde 3 halkevi çalışmalarına başlamıştır. 19321937 yılları arasında söz konusu bölgede her yıl mevcut halkevlerine 3-5 halkevi daha ilâve edilirken, 1938'den itibaren bölgede yeni açılan halkevlerinde belirgin bir artış söz konudur. Halkevleri sayısındaki asıl artış 19 Şubat 1939'da gerçekleşir. Bu tarihte Ege bölgesinde, aynı günde 34 
yeni halkevi birden açılır. Halkevi sayısındaki bu artışı İsmet İnönü'nün halkevleri konusunda yeni bir atılım yapma düşüncesine bağlayabiliriz. 1940 'tan sonra ise daha az sayıda halkevi açılmıştır. Bu durum 1940'tan sonra halkevlerinin açılamadığı yerlerde halkodalarının açılmasıyla izah edilebilir. Fakat 1946'dan sonra her hangi bir yerde halkevi açılmamasını hem halkevlerine karşı ilginin azalmasına hem de bölgenin halkevine doymasına bağlamak mümkündür.

\section{EGE BÖLÜMÜ HALKEVLERİ YAYIN ÇALIŞMALARI}

Halkevleri çalışmaları içinde yayınların ayrı bir yeri vardır. 19321951 yılları arasında halkevleri yayın sahasında birçok zorluğu yenmek suretiyle gerek kalite, gerek sayı bakımından epeyce bir mesafe almışlardır. Söz konusu dönemde belirleyebildiğimiz kadarıyla Ege Bölgesi halkevleri tarafından 129 eser yayımlanmıştır. İzmir, Aydın, Manisa ve Bergama halkevleri en fazla kitap ve dergi yayımlayan kurumlardır. Halkevleri yayınlarına genel olarak bakıldığında bu yayınları süreli yayınlar, edebî eserler, broşürler, araştırma eserleri, tercümeler, konferans metinleri ve öğüt kitapları olmak üzere 7 grupta toplamak mümkündür ${ }^{6}$.

2.1. Süreli Yayınlar: Süreli yayın, diğer bir deyişle dergi neşri halkevleri yayınlarının önemli bir bölümünü oluşturur. Dergilerdeki yazılar, genel olarak halkevlerinin kuruluş amaçları ile paralellik gösterir. Halkevleri dergilerinin nasıl bir yol tutup nelerle meşgul olacakları C.H.P. Nizamnamelerinde, C.H.P. Genel Sekreterliğinin Parti Teşkilâtına gönderdiği genel tebligatlarda, halkevleri çalışma talimatnamelerinde ve C.H.P halkevleri bürosunca yayımlanan diğer broşürlerde açıkça belirtilmiştir 7 . Düzenli olarak çıkmaları, yerel değerleri işlemeleri, çok sayıda araştırmac1, yazar ve şairin yetişmesine imkân vermeleri bakımından halkevleri dergileri bu kurumlar bünyesinde yapılan yayın çalışmalarının önemli bir ayağını oluşturur. Çoğunluğu 1933 'ten sonra çıkmaya başlayan bu dergiler Türkiye'deki yayım çalışmalarına yeni bir canlılık getirir. Ege bölge-

6. Avni Candar, "Halkevleri Neşriyatı", Konuşmalar, Broşür: 2, Ankara: 1940, ss. 228-229, ss. 228-230.

7. Bkz. Halkevleri Teşkilât, İdare ve Mesai Talimatnamesi, Hakimiyet-i Milliye Matbaası, Ankara: 1934, s. 11. C.H.F. Kâtibiumumiliğinin Fırka Teşkilâtına Umumî Tebligatı (Temmuz 1933'ten Birincikânun 1933 sonuna kadar), cilt: 3, Hakimiyet-i Milliye Matbaası, Ankara: 1934, 147 numaralı tamim, s. 43. C.H.P. Nizamnamesi, Onuncu Kısım, Madde 160, (Beşinci büyük kurultayın 1 Haziran 1939 tarihindeki toplantısında kabul edilmiștir), Ulus Basımevi, Ankara: 1939, s. 39. İmzasız, "Dergiler", Konuşmalar-Broşür2, C.H.P. Halkevleri Neşriyatı, Ankara: 1940, s. 235. 
sinde 9 halkevi dergisi çıkar. Fikirler, Güzel Günler, Yeni Doğuş, Yeni Milâs, Inanç, Muğla, Gediz, Ocak ve Küçük Menderes bölgede yayımlanan halkevi dergileridir.

2.1.1. Fikirler: İzmir kültür hayatında önemli yeri olan ve yayım hayatını 23 yıl sürdüren Fikirler İzmir'de en uzun süre neşredilen bir kültürsanat dergisidir. Fikirler dergisini eski Millî Eğitim bakanlarından Mustafa Necati Bey'in önemli katkılarıyla ${ }^{8}$ İzmir Mıntıkası Maarif Eminliği (müdürlüğü) 1927 Haziranında yayımlamaya karar verir ${ }^{9}$. Derginin kurucuları İzmir' in eski maarif müdürlerinden Fuat ve Mithat beylerdir ${ }^{10}$. Fikirler 1 Temmuz 1927-Haziran 1950 tarihleri arasında 370 sayı çıkmıştır. Dergi 30. sayıya kadar (1 Ocak 1929) eski harflerle, bu sayıdan itibaren yeni harflerle yayımlanır. 1936'da çıkan 133. sayıdan sonra dönemin İzmir Valisi Avni Doğan'nın teşvik ve desteğiyle İzmir Halkevi bünyesine katılır. Dergi uzun süre yayımlandığından dolayı farklı yazar kadrosu tarafından çıkarılmışır. Fikirler'de 1936'dan sonra, bir yandan eski yazar kadrosunun yazıları yayımlanırken; öte yandan bu kadroya yeni ve genç isimler ilâve edilmiştir. Fikirler'de sürekli yazan yazar, şair ve araştırmacılardan bazılarını alfabetik olarak şöyle sıralayabiliriz: Abidin Elderoğlu, Akil Koyuncu, Attila İlhan, Baha Arıkan, Berin Taşan, Cahit Irgat, Ceyhun Atuf Kansu, Edip Cansever, Fuat Edip Baksı, Fuat Muratoğlu, Gaye Nail Ozanoğlu, Hakkı Baha Pars, Halil Dumanoğlu, Hüseyin Avni Ozan, İbrahim Zeki Burdurlu, Kemal Bekir Manav, Kemâl Dayan, Kemâl Göksel, Kemal Kâmil Aktaş, Mustafa Rahmi Balaban, Mahmu R. Gazimihal, Metin Eloğlu, Mustafa Şerif Onaran, Şinasi Özdenoğlu, Nahit Ulvi Akgün, Necati Cumalı, Oğuz Harzem, Orhan Hançerlioğlu, Samim Kocagöz, Suat Taşer, Şükran Kurdakul, Talip Apaydın, Vedide Baha Pars, Ziya Somar.

Fikirler dergisinde özellikle 1936-1940 yılları arasında çoğunluğu felsefe grubu olmak üzere pek çok konuda yazı yayımlanmıştır. Dergide felsefe grubu yazılarının, özellikle de pedagoji yazılarının çok olması, dergi idarecilerinin genellikle eğitimcilerden oluşmasından kaynaklanır. Ancak 1940 'tan sonra Fikirler İzmir'de yaşayan edebiyat çevrelerinin yönetimine geçmiş, zamanla tamamen edebî bir kimliğe bürünmüştür. Halkevinden aldığı maddî güęle İzmirli bilim, kültür ve sanat adamları için bir okul vazifesi görmüş̧; Türk kültür hayatında bir dönem İzmir'i başarıyla

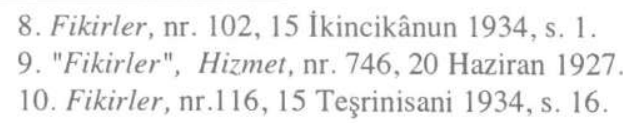


temsil etmiştir. Fikirler İzmir ve Ege bölgesinde yaşayan çok sayıda genç yeteneğin yetişmesini sağlamak suretiyle kültür ve edebiyat dünyasına yeni isimler kazandırmış; aynı zamanda Cumhuriyet dönemi edebî yönelimlerinin ortaya çıkmasında önemli bir rol oynamıştır.

2.1.2. Güzel Günler: Yayınına halkevleri kurulmadan önce başlayan Güzel Günler'in ilk üç sayısı Cumhuriyet Halk Partisi İzmir Vilâyet Merkezi tarafından çıkarılmıştır. Derginin 4. Sayısı İzmir Halkevi tarafından yayımlanır. Güzel Günler 26 Aralık 1931-29 Ekim 1933 tarihleri arasında dört sayı çıkar. Dergide yüksek edebî değere sahip eserler yerine daha çok didaktik, güdümlü ve propaganda amaçlı eserler yayımlanır. Ayrıca dergide çıkan ve Cumhuriyetin ilk on yılıyla ilgili yazılan makaleler sosyal tarih araştırmacıları için önemli sayılabilecek yazılardır.

2.1.3.Yeni Doğuş: Yeni Doğuş, Manisa Halkevi'nin yayımladığı ilk dergidir. 29 Ekim 1933-Haziran 1935 tarihleri arasında 17 sayı çıkar. Aylık bir dergidir. Dergide çıkan edebî eserler genellikle inkılâbı anlatan edebiyat örnekleridir. Bununla beraber edebiyatımızda İkinci yeni hareketinin önemli temsilcilerinden biri sayılan İlhan Berk'in Ahmet Haşim etkisiyle yazdığı ilk şiirlerinin bu dergide çıkması Yeni Doğuş'un önemini arttırmaktadır.

2.1.4. Yeni Milâs: Milâs Halkevi tarafından yayımlanan Yeni Milâs 29 Ekim 1936-Mayıs 1937 tarihleri arasında 8 sayı çıkar. Diğer halkevleri dergilerinde olduğu gibi, Yeni Milâs da genel içerikli bir dergidir. Şiir, hikâye, ve ciddî yerel folklor incelemeleriyle Feridun Alkan Yeni Milâs'in en fazla dikkati çeken yazarıdır. Ayrıca Haydar Çelik'in tezli hikâyeleri, Nahit Menteşe'nin bilhassa Alman şiir ve nesrinden yaptığı tercümeler derginin başlıca edebî muhtevasını oluşturur. Yeni Milâs zayıf içerikli bir süreli yayındır.

2.1.5. İnanç: Mart 1937-Eylül 1946 tarihleri arasında 106 sayı çıkmıştır. Denizli Halkevi Dil ve Edebiyat Şubesi tarafından yayımlanmıştır. Aylık bir süreli yayındır. Dergide yaklaşık 200 değişik yazar ve şairin yazısı vardır. Ali Ulvi Darıverenli, Ahmet Vefa Aray, Ata Lütfi Özdil, Fahri Akçakoca Akça, Fehmi Erdoğan, Hüseyin Yağcı, Necdet Şenel, Tahsin Saygunışık, Şükrü Elçin, Denizli Halkevi dergisinde yazıları en çok yayımlanan yazar ve şairlerdir. İnanç diğer halkevi dergilerinin aksine adını tarihten ve birazda Atatürk döneminin inançlı ruhundan almıştır. Derginin adı Denizli ve civarında bir dönem hüküm süren İnançoğulları devletine dayanmaktadır. Şiir, hikâye, mensur şiir, piyes, tenkit ve hatırat 
yazılarının yanı sıra İnanç'ta edebiyatın çeşitli alanlarında yapılan çok sayıda inceleme yazısı ve derleme vardır. İnanç daha çok kültür-sanat ağırlıklı bir dergidir. Yazarların gayretli çalışmalarıyla soğuk yüzlü ve basit yazıları içeren bir halkevi dergisi olmaktan çıkmayı başaran ender halkevi dergilerinden biridir. Denizli ve çevresi aydınları için bir okul olan İnanç, Ege bölgesinin İzmir'den sonra ikinci büyük kültür merkezi olan Denizli'de kültürel alanda önemli bir boşluğu gidermiştir.

2.1.6. Muğla: Muğla Halkevi’nin yayın organı olan Muğla dergisi 1 Mart 1937-Temmuz 1938 tarihleri arasında 17 sayı çıkmıştır. Aylık periyotlar halinde ve düzenli olarak yayımlanan bir dergidir. Tahir Hayrettin Tolga, Cavit Aker, Ekmel İzdem, Zekâi Eroğlu, Selim Yatağan, Muammer Lütfi Bahşi, Mahir Balkı ve Hikmet Turhan Dağlığlu derginin başlıca yazar ve şair kadrosunu oluştururlar. Muğla dergisinde şiir, hikâye, tiyatro, tenkit, gezi yazısı, fantezi ve deneme türünde yazılmış edebî nitelikli yazılar vardır. Ayrıca mani, destan, masal, halk hikâyesi gibi Muğla ve civarından derlenen halk edebiyatı ürünleri yayımlanmıştır. Kısa ömürlü bir halkevi dergisi olan Muğla, içinde bazı folklor derlemeleri ve birkaç değerli şiir ihtiva etmekle beraber, hem edebî hem de kültürel yönden Ege'de yayımlanan en zayıf halkevi dergilerden biridir.

2.1.7. Gediz: Manisa Halkevi'nin yayımladığı ikinci dergi olan Gediz 23 Nisan 1937-Nisan 1950 tarihleri arasında 104 sayı çıkmıştır. Aylık bir dergidir. Dergiyi 1937'de Manisa Halkevi başkanı Azmi Önakın ile Manisa İnhisarlar Baş Müdürü Mustafa Dümer kurmuşlardır ${ }^{11}$. Gediz'de 150 'den fazla değişik kalemin yazısı vardır. Gediz'i diğer halkevi dergilerden farklı hâle getiren en önemli özellik bu dergide yerel tarih incelemelerine verilen önemdir. Dergide Manisa'nın tarihî, sosyal, kültürel, ekonomik ve ticarî yönleriyle ilgili yazıların yanı sıra, Manisa'yı ilgilendiren orijinal her türlü yazıyı bulmak mümkündür. Bilhassa Mustafa Çağatay Uluçay, İbrahim Gökçen ve Kâmil Su gibi tarih araştırmacıları Manisa'nın şeri'ye sicillerine dayanan yerel tarihle ilgili araştırmalarını önce Gediz'de yayımlamışlar; daha sonra Manisa Halkevi adına kitap olarak bastırmışlardır ${ }^{12}$. Bu araştırmalar günümüzde de önemini kaybetmeyen ciddî ve emek mahsulü çalışmalardır. Bu bakımdan Gediz yerel tarih araştırması denildiğinde ilk akla gelen süreli yayınlardan biridir.

11. "Gediz Sekizinde" Gediz, nr. 84, 1 Eylül 1945, s.2, ss. 2-3.

12. Manisa ve çevresinin tarihiyle ilgili Gediz'de çıkan ve daha sonra kitap halinde yayımlanan yazıların bir değerlendirmesi için bkz. Taşdemir. Türkiye'de Tarih Bilinci Oluşmasinda Halkevlerinin Rolui, ss. 161-179. 
2.1.8. Ocak: Urla Halkevi tarafından yayınlanan Ocak 19 Şubat 1939-19 Mayıs 1939 tarihleri arasında iki sayı çıkar. Ocak kısa ömürlü bir halkevi dergisi olmasına rağmen, Necati Cumalı, Nihat Kobek ve Cihat Gökçek gibi güçlü yazar kadrosu sayesinde edebiyat tarihinde adından söz ettiren bir dergi olmayı başarmıştır. Necati Cumalı'nın ilk şiiri ve ilk tenkit yazısı bu dergide yayımlanır. Ocak kültür, sanat ve edebiyat içerikli bir dergidir.

2.1.9. Küçük Menderes: Tire Halkevi tarafından yayımlanan Küçük Menderes 25 Nisan 1940-23 Nisan 1942 tarihleri arasında 12 sayı çıkar. Dergi, bazen iki aylık bazen üç aylık periyotlarla yayımlanmıştır. Ziya Hanhan, Nahit Nafiz Edgüer, Muammer Dülger, Ekrem Özelmas, Halit Nafiz Edgüer ve Türkân Ülke derginin başlıca yazar kadrosunu oluşturur. Dergide çıkan gerek edebî, gerek bilimsel nitelikli yazılarda Tire ve çevresine anlatan yerel konular işlenmiştir. Küçük Menderes değerli bir yerel dergidir.

Kısaca Ege bölgesinde açılan 79 halkevinden yedi tanesi dergi yayımlamıştır. Bölgede yayımlanan halkevleri dergilerinin muhtevasına genel olarak bakıldığında şu hususları görmek mümkündür: 1-Cumhuriyet dönemi Türk edebiyatına yön veren isimlerden bir kısmı bu dergilerin etrafında oluşan kültür muhitinde yetişmişler ve eserlerinden bazılarını halkevleri dergilerinde yayımlamışlardır. 2-Bilhassa İnanç, Gediz ve Küçük Menderes dergileri yerel folklor derlemeleri açısından zengindir. 3-Dergilerin hemen hepsinde Yeni Türk Edebiyatı, Eski Türk Edebiyatı, Halk edebiyatı ve Türk Dili incelemelerine dair pek çok makale yayımlanmıştır. 4-Dergilerde başta yerel tarih olmak üzere, etnografya, arkeoloji, felsefe, eğitim, psikoloji, sosyoloji, tarım ve ziraat, halk sağlığı ve fen bilimlerinin çeşitli kollarına dair makale vardır. Bu yazılar analiz edildiğinde Cumhuriyet döneminin bilimsel ve edebî yönelimleri hakkında bazı keskin dikkatlerin elde edilmesi mümkündür.

2.2. Edebî Eserler: Ege halkevleri tarafından 6 tane edebî eser yayımlanır. İzmir Halkevi bu alanda en önde gelir. Rahmi Balaban'ın Özdemir Onbaşı ve Şehir mi Tövbeler Tövbesi, Fuat Edip Baksı'nın Gökçen Efe adlı manzum destanı, Necati Cumalı'nın Boş Beşik adlı piyesi İzmir Halkevi yayınları arasında çıkan edebî eserlerdir. Ayrıca Manisa Halkevi İlhan Berk' in Güneşi Yakanların Selâmı ve Ödemiş Halkevi de Muammer Lütfi Bahşi'nin İlk Kurşun adlı eserlerini yayımlar. Edebî eserler genel- 
Tablo 6: Ege Bölgesi Halkevleri Dergilerinin Kronolojik Tablosu.

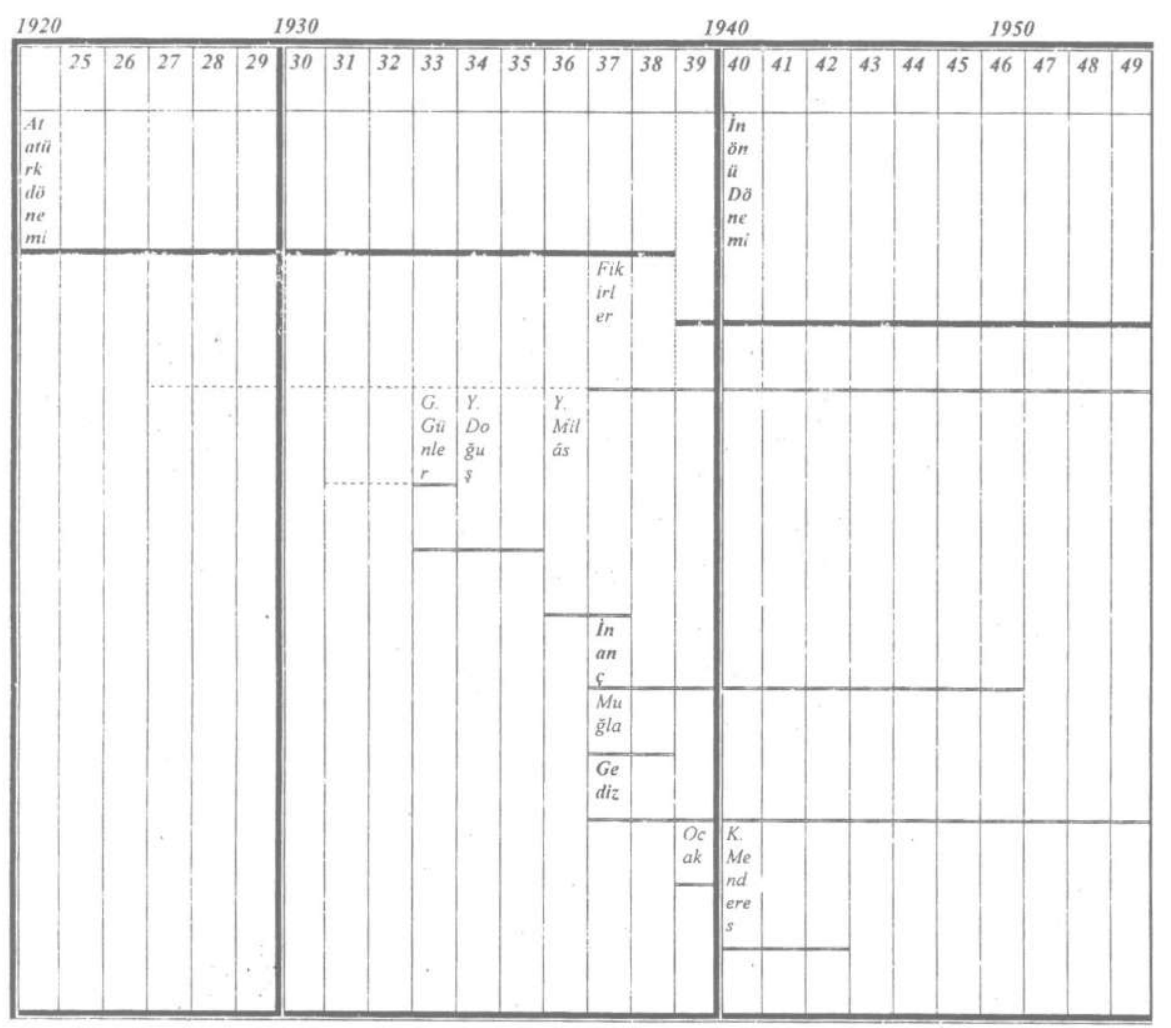

29 Ekim 1923 : Cumhuriyet ilân edildi.

1 Haziran 1927 : Fikirler dergisinin ilk sayısı yayımlandı.

1 Ocak 1929 :Ülke genelinde Yeni Türk Harflerinin kullanımına geçildi.

19 Subat 1932 :Halkevleri açıldı.

29 Ekim 1933 :Yeni Doğuş ve Güzel Günler halkevi dergisi olarak yayımland

1 Şubat 1936 :Fikirler İzmir Halkevi bünyesine katıld.

11 Kasım 1939 :İsmet İnönü Cumhurt.sşkanı oldu.

1939 :Íkinci Dünya Savaşı başladı.

1945 :Ikinci Dünya Savașı sona erdi.

Haziran 1950 :Fikirler yayın hayatına son verdi. 
likle halkevi mensuplarının çalışmalarıdır. Yayımlanan eserlerde yerel temalar işlenmiştir.

2.3. Broşürler: 1932-1950 arasında Ege'deki halkevleri 22 kadar broşür yayımlamıştır. Bunların içeriği yayımlayan halkevinin çalışmaları ve başarıları olmakla beraber, mahalli bir çok özellikleri ortaya çıkardıkları için ayrı bir değerleri vardır. Bilhassa 1938 yılında Cumhuriyetin Onbeşinci yılı için hemen her ilin halkevi tarafından hazırlanan broşürler dikkati çeker. Bu broşürlerde 1923-1938 arasında 15 yıllık dönemde ilgili vilâyetteki sosyal, ekonomik, kültürel v.b. gelişmeler istatistikler verilmek suretiyle anlatılmıştır. Osmanlı dönemi ile Cumhuriyet dönemi arasında mukayeseler ve yörenin çağdaşlaşma yolunda attığı adımlar çok güzel bir şekilde ortaya konmuştur. Bunlar Türkiye tarihinde 15 yıllık dönemde sosyal ve kültürel kalkınmayı göstermesi bakımından önemli çalışmalardır. Çoğunun içeriği inkılâp tarihimize önemli doküman verecek mahiyette düzenlenmiştir.

2.4. Araştırma Eserleri: Halkevleri yayımlarının yarısına yakınını mahalli ya da başka sahalara ait araştırma eserleri oluşturur. Araştırma eseri diye niteleyebileceğimiz 51 kitap yayımlanmıştır. İzmir Aydın, Bergama ve Manisa halkevleri bu alanda başarılı çalışmalar yapmışlardır. Yörenin tarihi, ziraatı, etnografyası, edebiyatı, folkloru, musikîsi, âdetleri ve daha bir çok özellikleri üzerinde yapılan ve yayımlanan bu eserlerin çeşitli bilimsel sahalardaki araştırmalarda ehemmiyeti inkâr edilemez bir gerçektir. Bu eserler arasında öyleleri vardır ki başlı başına bilimsel araştırmalardır; Hatta temel bir başvuru kaynağıdır. Bunlar bölgenin belirli ölçüde bilimsel hazinesini oluşturacak mahiyettedir.

2.5. Tercümeler: Başta İzmir Halkevi olmak üzere bazı halkevleri, değerli bir hizmet olarak, yabancı dillerde yayımlanmış değerli eserlerin tercümelerini yaptırmışlardır. Bu tercümeler Aristo, Eduardo Claparede, Emile Butro, Jean Jacque Rousseau, Willian James gibi batılı filozof ve eğitimcilerin eserlerinden oluşur. Söz konusu eserlerin önemli bir bölümü İzmir'de Bergamalı Profesör olarak tanınan meşhur eğitimci Mustafa Rahmi Balaban tarafından dilimize aktarılmıştır. Türkiye gibi dış ülkelerin bilimine, düşünüşüne fazla muhtaç olan ve ancak cumhuriyetle beraber hakiki bilim sahasında ilerlemeye başlamış olan bir ülkede bu tercümelerin kıymet ve önemi başka ülkelere göre bir kat daha fazladır. Söz konusu dönemde herhangi bir kitabı yayımlamak için maruz kaldığımız zor- 
luk göz önüne alınırsa, İzmir halkevinin bu alandaki çalışmaları takdire lâyık çalışmalardır.

2.6. Konferans Metinleri: Halkevleri talimatnamelerinde halkevlerinde verilen konferansların yayımlanması zorunluluğu vardır. Ancak bu kural tam anlamıyla yerine getirilememiştir. Bununla beraber Bazı halkevleri düzenledikleri konferansların metinlerini yayımla yoluna gitmișlerdir. Aydın ve Turgutlu halkevleri bu konuda öne çıkan kurumlardır. Aydın Halkevi Hulusi Erdoğan'ın Iyon Medeniyeti ve Efes, Asaf Gökbel'in Tarih Bakımından Belediyecilik ve Mithat Yenen'in Sehirlerimizin Imar Davası başlıklı konferanslarını yayımlamıştır. Ege halkevleri yayınlarından 11'i konferans metnidir.

2.7. Öğ̈̈̈t Kitapları: Halkevlerinin bu sahadaki yayımları da dikkate değer çalışmalardır. Çünkü Türkiye'de yayımlanan eserlerin hemen hiç biri halka ve köylüye hitap etmez, edemez. Bizde aydınlar halka ve köylüye okumaz gözüyle bakarlar ve onlara hitap eden ve bilhassa onların hayatını anlatan konular üzerinde çalışmak mümkün olmaz. Bu sebeple Ege halkevleri bilhassa halk ve köylüye ait yeni ve orijinal bir kütüphane kurmuştur diyebiliriz. Yayımlanan eserlerden 19'u halk ve köylüyü bilinçlendirmeye yönelik öğüt kitaplarıdır. Aydın ve İzmir halkevleri bu alanda diğer halkevlerine göre biraz daha mesafe almışlardır. İncircilere, tütüncülere, pamukçulara, hayvan yetiştiricilerine yönelik olarak yazılan bu kitaplar basit, köylünün anlayacağı bir dille yazılmış, resimli kitaplardır. Kitapların önemli bir bölümünün Rahmi Balaban gibi değerli bir filozof ve eğitimci tarafından yazılması bu eserlerin önemini arttırmaktadır.

Yukarıda belirttiğimiz gibi Ege bölgesi halkevleri yayımları çok geniş ve derin bir alanı kaplamakta, hiçbir kişisel çıkarı gözetmeyerek halkın yükselmesini sağlayacak esaslara dayanmaktadır. Şunu da belirtmek isterim ki yayım çalışmaları halkevlerinin diğer sahalardaki çalışmalarıyla sıkı sıkıya bağlantılıdır. Bu çalışmaları tamamlamakta ve geliştirmektedir. Hatta söz konusu dönemde Türkiye'de yapılan bütün neşriyatın yaklaşık yüzde yirmisinin halkevleri tarafından yapıldığını iddia edilmektedir. Bu durum memleketteki bilimsel gelişmede halkevlerinin rolünü açıcça ortaya koymaktadır. 